\title{
Variation in Oxalic Acid Content among Commercial Table Beet Cultivars and Related Crops
}

\author{
Amy K. Freidig and Irwin L. Goldman ${ }^{1}$ \\ Department of Horticulture, University of Wisconsin, 1575 Linden Drive, Madison, WI 53706
}

\begin{abstract}
Additional INDEX words. Beta vulgaris, dietary oxalate, breeding, enzymatic quantification, nutrition, kidney stone formation

ABSTRACT. Oxalic acid $\left(\mathrm{C}_{2} \mathrm{O}_{4}{ }^{2-}\right)$ is a compound of interest as a result of its relationship with kidney stone formation and antinutritive properties. Because table beet [Beta vulgaris ssp. vulgaris (garden beet group)] is considered a high oxalate food, breeding to decrease oxalic acid levels is an area of interest. In this study, a field trial was conducted over $\mathbf{2}$ years for $\mathbf{2 4}$ members of the Chenopodiaceae using two different planting dates to determine if variation exists for both total and soluble oxalic acid levels in roots and leaves. Total and soluble oxalic acid was extracted from homogenized root core and leaf tissue samples and a colorimetric enzymatic assay was used to determine total and soluble oxalic acid levels. Mean values ranged from 722 to $1909 \mathrm{mg} / 100 \mathrm{~g}$ leaf tissue and 553 to $1679 \mathrm{mg} / 100 \mathrm{~g}$ leaf tissue for total and soluble oxalate levels, respectively. Beet cultivar Forono and swiss chard [B. vulgaris ssp. vulgaris (leaf beet group)] cultivar Burpee's Fordhook Giant Chard produced the respective highest and lowest soluble and total oxalic acid leaf levels. Swiss chard cultivars produced $38 \%$ less total oxalate compared with table beet cultivars based on overall means. Root soluble oxalate values ranged from 103 to $171 \mathrm{mg} / 100 \mathrm{~g}$ root tissue and total values ranged from 95 to $142 \mathrm{mg} / 100 \mathrm{~g}$ root tissue. Significant variation for both total and soluble oxalic acid levels were detected, indicating progress could be made toward breeding for lower oxalic acid levels in table beet. However, gains in oxalic acid nutritional quality may be limited because it would take a substantial decrease in levels for table beet to be reclassified as a low oxalate food.
\end{abstract}

Oxalic acid $\left(\mathrm{C}_{2} \mathrm{O}_{4}{ }^{2-}\right)$ is a component of many commonly eaten foods and is of interest as a result of its antinutritive properties. Table beet, a vegetable crop grown for both its roots and leaves, is considered by the National Kidney Foundation to be a food high in oxalic acid (Council on Renal Nutrition, 2009). Potential health associations of oxalic acid (synonymous in this article with oxalate) are decreased bioavailability of other nutrients and increased risk of kidney stone formation in those predisposed to the disease (Brogren and Savage, 2003; Holmes et al., 2001; Morris et al., 2007; Nakata and McConn, 2006; Robertson and Nordin, 1969). Many commonly consumed food crops contain oxalate such as spinach (Spinacia oleracea), beet, tea (Camellia sinensis), and chocolate.

Soluble oxalic acid can be found in many plant tissues as potassium, sodium, or ammonium oxalate salts. Oxalic acid also forms insoluble compounds with cations such as calcium or magnesium (Hodgkinson, 1977). Evidence has suggested that glyoxylate, oxaloacetate, glycolate, and other tricarboxcylic acid cycle intermediates were possible precursors to oxalate in plants (Chang and Beevers, 1968; Franceschi and Loewus, 1995). Additionally, L-ascorbic acid $\left(\mathrm{C}_{6} \mathrm{H}_{8} \mathrm{O}_{6}\right)$ is a major oxalic acid precursor (Nuss and Loewus, 1978; Yang and Loewus, 1975). Biosynthesis includes cleavage at the $\mathrm{C} 2 / \mathrm{C} 3$ position of ascorbic acid, but the full biosynthetic pathway is unknown (Libert and Franceschi, 1987).

Oxalic acid levels depend on the type and age of plant tissue as well as growth rate (Albihn and Savage, 2001; Kaminishi and Kita, 2006; Morita et al., 2004). Additional sources of variation

Received for publication 15 Sept. 2010. Accepted for publication 9 Nov. 2010. We thank Beth Ann Workmaster for her technical assistance.

${ }^{1}$ Corresponding author. E-mail: ilgoldma@wisc.edu. include cultivar selection, measurement method, and environmental conditions. Although age of tissue has been studied, little is known about the effects of delaying planting date on oxalic acid levels. Roles of oxalate in plant tissue include physical or chemical defense against herbivory, calcium regulation by adding calcium storage sites, and regulation of cations or deleterious compounds such as excessive aluminum (Franceschi, 1989; Franceschi and Loewus, 1995; Korth et al., 2006; Ma and Miyasaka, 1998; Ruiz et al., 2002). Various studies have quantified oxalic acid levels in vegetables (Mou, 2008; Savage et al., 2000).

Because of the role dietary oxalate plays in disease and nutrition, breeding for lower levels of oxalic acid is an area of interest. Table beet roots and leaves are considered high oxalate foods and recommendations suggest avoidance if trying to reduce oxalate intake. In this study we screened commercially available table beet cultivars and related species \{ such as mangel [B. vulgaris ssp. vulgaris (fodder beet group)] and swiss chard to determine if variation in soluble and total oxalic acid levels exists in both roots and leaves. Many beet cultivars remain openpollinated rather than hybrid and thus are a potential source of genetic diversity for future breeding. Additionally, variation may exist within a single cultivar maintained by different seed companies. We therefore also screened a single cultivar sold by three different seed companies to determine if variation exists within a cultivar. The effect of planting date was also tested to determine if cultural methods could be used to reduce oxalic acid levels.

\section{Materials and Methods}

Plant material. Twenty-four members of the Chenopodiaceae were used in this experiment (Table 1). Six different seed suppliers were used to sample existing commercial beet, chard, 
Table 1. Commercial source, cultivar name, and species designation for cultigroups of table beet (garden beet group), mangel (fodder beet group), and swiss chard (leaf beet group) cultivars of Beta vulgaris ssp. vulgaris planted for oxalic acid screening in 20082009 .

\begin{tabular}{|c|c|c|}
\hline Source & Cultivar & Cultigroup \\
\hline \multirow[t]{10}{*}{$\begin{array}{l}\text { Johnny's Selected } \\
\text { Seeds (Winslow, ME) }\end{array}$} & $\begin{array}{l}\text { Early Wonder } \\
\text { Tall Top }\end{array}$ & Garden beet group \\
\hline & Big Top & Garden beet group \\
\hline & Touchstone Gold & Garden beet group \\
\hline & Blakoma & Garden beet group \\
\hline & Forono & Garden beet group \\
\hline & Chioggia & Garden beet group \\
\hline & Red Ace & Garden beet group \\
\hline & $\begin{array}{l}\text { Burpee's Rhubarb } \\
\text { Chard }^{z}\end{array}$ & Leaf beet group \\
\hline & $\begin{array}{l}\text { Burpee's Fordhook } \\
\text { Giant Chard }\end{array}$ & Leaf beet group \\
\hline & Bull's Blood & Garden beet group \\
\hline \multirow{4}{*}{$\begin{array}{l}\text { J.W. Jung Seed } \\
\text { Co.(Randolph, WI) }\end{array}$} & Lutz Green Leaf & Garden beet group \\
\hline & Burpee's Golden & Garden beet group \\
\hline & Golden Eckendorf $^{y}$ & Fodder beet group \\
\hline & $\begin{array}{l}\text { Mammoth } \\
\text { Long Red }\end{array}$ & Fodder beet group \\
\hline \multirow{4}{*}{$\begin{array}{l}\text { Gourmet Seed } \\
\text { International } \\
\text { (Tatum, NM) }\end{array}$} & Bikores & Garden beet group \\
\hline & Bolivar & Garden beet group \\
\hline & Jaune de Vauriac & Garden beet group \\
\hline & Rote Kugal & Garden beet group \\
\hline \multirow[t]{3}{*}{ NE Seed (Hartford, CT) } & Egitto Miglionata & Garden beet group \\
\hline & Detroit Dark Red & Garden beet group \\
\hline & Yellow Detroit & Garden beet group \\
\hline \multirow[t]{2}{*}{ Seedway (Hall, NY) } & Detroit Dark Red & Garden beet group \\
\hline & Ruby Queen & Garden beet group \\
\hline $\begin{array}{l}\text { W. Atlee Burpee and } \\
\text { Co. (Warminster, PA) }\end{array}$ & Detroit Dark Red & Garden beet group \\
\hline
\end{tabular}

${ }^{\mathrm{z}}$ Swiss chard cultivar.

${ }^{\mathrm{y}}$ Mangel cultivar.

and mangel cultivars. All cultivars were open-pollinated varieties with the exception of the hybrid cultivar Red Ace. Three different seed company sources of cultivar Detroit Dark Red were used to observe if open-pollinated populations from different seed companies produced similar levels of oxalate. However, it cannot be confirmed that the different seed sources are assuredly from different populations because two of the companies purchase seed from unknown sources.

FiELd DESIGN. Using a randomized complete block design, cultivars were direct seeded in 3.7-m-long rows spaced $46 \mathrm{~cm}$ apart at Arlington Research Farm (University of Wisconsin Horticulture Research Farm, Arlington, WI). There were two plantings per field season. Initial planting dates were 29 May 2008 and 4 June 2009 and are referred to as the standard planting dates to reflect standard planting times for table beet in the midwestern United States. The later planting dates were 3 July 2008 and 1 July 2009 and are referred to as the late planting date. Before planting, pre-emergent herbicides cycloate (Ro-Neet; Stauffer Chemical Co., Westport, CT) and chloridazon (Pyramin; Nufarm Australia, Victoria, Australia) were applied to the field. The experimental unit was a cultivar/entry and three replicates were used in this experiment. All cultivars were included in both plantings. Each planting was surrounded on both sides by a guard row of standard table beet cultivar Ruby Queen. The field was hand-weeded until harvest on 25 to 29 Aug. 2008 and 8 to 9 Sept. 2009.

Ten whole plants were selected at random from each row and these comprised samples. All samples were bulked per row. The fourth or fifth oldest fully developed leaf (minus the petiole) was sampled from each plant and stored on ice until frozen at $-17.25^{\circ} \mathrm{C}$. The root of each plant was sampled by removing a cylinder $1 \mathrm{~cm}$ in diameter and $2 \mathrm{~cm}$ deep using a core-borer. Samples were removed from the thickest part of the root and included skin. Root samples were frozen at $-17.25^{\circ} \mathrm{C}$. No root samples were taken for swiss chard cultivars.

EXTRACTION OF TOTAL AND SOLUBLE OXALIC ACID. Oxalic acid extraction and measurement were performed similarly to the methods described by Chai and Liebman (2005). Leaves were ground in an industrial blender in a ratio of $3 \mathrm{~g}$ water to $1 \mathrm{~g}$ bulked leaf tissue for $2 \mathrm{~min}$. Roots were chopped in a hand chopper for $30 \mathrm{~s}$ and ground in an industrial blender for $1 \mathrm{~min}$ in a ratio of $2 \mathrm{~g}$ water to $1 \mathrm{~g}$ bulked root tissue. Two and a half milliliters of the homogenate were removed and its mass was measured. To extract soluble oxalate, $5 \mathrm{~mL}$ of double deionized water was added to the homogenate and allowed to incubate for $15 \mathrm{~min}$ at room temperature. Total oxalate (soluble and insoluble) was extracted with $2 \mathrm{~N} \mathrm{HCl}$. The extraction temperature of 20 to $23{ }^{\circ} \mathrm{C}$ (room temperature) was chosen to minimize the spontaneous generation of oxalate (Honow and Hesse, 2002). Samples were then centrifuged at $11,265 g_{\mathrm{n}}$ for $15 \mathrm{~min}$. Five milliliters of the supernatant was removed and set aside. The extraction process was repeated a total of three times per $2.5-\mathrm{mL}$ sample. Once a total of $15 \mathrm{~mL}$ of extract was collected, the extract was diluted with double deionized water to a volume of $25 \mathrm{~mL}$ and then inverted. Extracts were frozen at $-17.25^{\circ} \mathrm{C}$ until assayed.

Analysis of total and SOluble oxaliC ACID LeVels. Soluble and total oxalic acid levels were determined on a fresh weight basis using an enzymatic assay kit (Trinity Biotech, Bray, U.K.). This colorimetric assay uses two reactions. Initially, in the presence of oxalate oxidase, oxalate will oxidize into $\mathrm{H}_{2} \mathrm{O}_{2}$ and $\mathrm{CO}_{2}$. Next, $\mathrm{H}_{2} \mathrm{O}_{2}$ will react with $\mathrm{MBTH}$ (3-methyl-2benzothiazolinone hydrazone) and DMAB [3-(dimethylamino) benzoic acid] in the presence of peroxidase to produce the detectable indamine dye. Volumes were scaled down for use in a 96-well microplate. Reagents were prepared according to the kit instructions. Thawed samples were added to $500 \mathrm{uL}$ of sample diluent (EDTA, buffer). Root extracts were added at full strength to the sample diluent. Leaf extracts were diluted with double deionized water until the ratio of water:leaf extract was $3: 1$. The $\mathrm{pH}$ of all samples was adjusted using $1 \mathrm{~N} \mathrm{NaOH}$ or $1 \mathrm{~N} \mathrm{HCl}$ until between $\mathrm{pH} 5$ and $\mathrm{pH}$ 7. Approximately $1 \mathrm{~mL}$ of the $\mathrm{pH}$-adjusted solution was added to a microcentrifuge tube containing between 0.3 to $0.5 \mathrm{~mL}$ of activated charcoal. Samples were shaken by hand for $5 \mathrm{~min}$ and then spun down for $5 \mathrm{~min}$ at $705 g_{\mathrm{n}}$ in a benchtop centrifuge.

Once centrifuged, $10.8 \mu \mathrm{L}$ of the purified sample was removed and added to a microplate well containing $217.3 \mu \mathrm{L}$ of Reagent A (DMAB, MBTH, buffer). Reagent B (oxalate oxidase, peroxidase) was added to induce the reaction. The plate was allowed to incubate for $5 \mathrm{~min}$ at room temperature. Samples were read at $595 \mathrm{~nm}$ on a microplate reader and were analyzed in analytical duplicates. A water blank and three prepared oxalate standards $\left(25,50\right.$, and $\left.100 \mathrm{mg} \cdot \mathrm{L}^{-1}\right)$ were included in each run (Sigma-Aldrich, St. Louis, MO). 
Statistical ANAlysis. Data were analyzed with an analysis of variance using the PROC MIXED procedure of SAS (Version 9.1.3; SAS Institute, Cary, NC). All variables were treated as fixed except for replication, which was considered random. Means were compared using Fisher's protected F test. Root data from the second planting of 2009 were eliminated from analysis as a result of many missing data points caused by insufficient root size.

\section{Results and Discussion}

LEAvES. We observed a significant planting date $\times$ cultivar interaction for both soluble and total oxalate levels (Table 2). The interaction was primarily the result of a change in magnitude of means rather than rank. The change in magnitude may have been the result of the standard planting date having $\approx 1$ month longer in the field to accumulate oxalate compared with the late planting date. Because the majority of cultivar means ranked consistently across planting dates, we averaged over planting dates for general cultivar comparisons (Table 3). Mean values ranged from 722 to $1909 \mathrm{mg} / 100 \mathrm{~g}$ leaf tissue and 553 to $1697 \mathrm{mg} / 100 \mathrm{~g}$ leaf tissue for total and soluble oxalate levels, respectively. 'Forono', a cylindrical red beet, had the highest soluble and total oxalate values and differed significantly from all other cultivars. 'Burpee's Fordhook Giant Chard' produced the lowest values for both soluble and total oxalate and differed significantly from all other cultivars.

Table 2. Analysis of variance using the PROC MIXED procedure of SAS (Version 9.1.3; SAS Institute, Cary, NC) for leaf soluble and total oxalate levels evaluated for the youngest fully developed leaf at vegetable maturity as determined by an enzymatic assay for 24 beet [Beta vulgaris ssp. vulgaris (garden beet group)] and related sub-species cultivars grown in replicated trials at Arlington, WI, in 2008-2009.

\begin{tabular}{|c|c|c|c|c|c|}
\hline Trait & $\begin{array}{c}\text { Source of } \\
\text { variation }\end{array}$ & $\mathrm{df}_{\text {num }}{ }^{\mathrm{z}}$ & $\mathrm{df}_{\mathrm{den}}^{\mathrm{y}}$ & $P$ & Significance \\
\hline \multirow{7}{*}{$\begin{array}{c}\text { Leaf soluble } \\
\text { oxalate }\end{array}$} & Planting date & 1 & 8 & 0.0240 & $*$ \\
\hline & Year & 1 & 8 & 0.4286 & NS \\
\hline & Cultivar & 23 & 181 & $<0.0001$ & $* * *$ \\
\hline & Year $\times$ cultivar & 23 & 181 & 0.0707 & NS \\
\hline & $\begin{array}{l}\text { Planting date } \times \\
\text { cultivar }\end{array}$ & 23 & 181 & $<0.0001$ & $* * *$ \\
\hline & $\begin{array}{l}\text { Year } \times \text { planting } \\
\text { date }\end{array}$ & 1 & 8 & 0.5849 & NS \\
\hline & $\begin{array}{l}\text { Year } \times \text { planting } \\
\text { date } \times \text { cultivar }\end{array}$ & 23 & 181 & 0.4869 & NS \\
\hline \multirow{7}{*}{$\begin{array}{r}\text { Leaf total } \\
\text { oxalate }\end{array}$} & Planting date & 1 & 8 & 0.0067 & $* *$ \\
\hline & Year & 1 & 8 & 0.4438 & NS \\
\hline & Cultivar & 23 & 182 & $<0.0001$ & $* * *$ \\
\hline & Year $\times$ cultivar & 23 & 182 & 0.0100 & $* *$ \\
\hline & $\begin{array}{l}\text { Planting date } \times \\
\text { cultivar }\end{array}$ & 23 & 182 & 0.0024 & $* *$ \\
\hline & $\begin{array}{l}\text { Year } \times \text { planting } \\
\text { date }\end{array}$ & 1 & 8 & 0.9341 & NS \\
\hline & $\begin{array}{l}\text { Year } \times \text { planting } \\
\text { date } \times \text { cultivar }\end{array}$ & 23 & 182 & 0.8798 & NS \\
\hline
\end{tabular}

${ }^{\mathrm{z} N u m e r a t o r} \mathrm{df}$.

${ }^{\mathrm{y}}$ Denominator $\mathrm{df}$.

NS, ${ }^{*}, * *, * * *$ Nonsignificant or significant at $P \leq 0.05,0.01$, or 0.001 , respectively.
Table 3. Leaf mean soluble and total oxalate values for the youngest fully developed leaf at vegetable maturity as determined by an enzymatic assay for 24 beet [Beta vulgaris ssp. vulgaris (garden beet group)] and related sub-species cultivars grown in replicated trials at Arlington, WI, in 2008-2009 and compared using a protected $\mathrm{F}$ test.

\begin{tabular}{|c|c|c|}
\hline \multirow[b]{2}{*}{ Cultivar } & \multicolumn{2}{|c|}{ Leaf soluble oxalate Leaf total oxalate } \\
\hline & \multicolumn{2}{|c|}{$(\mathrm{mg} / 100 \mathrm{~g}$ leaf tissue $)$} \\
\hline Big Top & 1337.0 & 1602.5 \\
\hline Bikores & 1134.6 & 1381.2 \\
\hline Blakoma & 828.4 & 1122.9 \\
\hline Bolivar & 1149.3 & 1407.2 \\
\hline Bull's Blood & 1142.8 & 1397.2 \\
\hline $\begin{array}{l}\text { Burpee's Fordhook } \\
\text { Giant Chard }{ }^{z}\end{array}$ & 553.1 & 721.7 \\
\hline Burpee's Golden & 983.5 & 1198.3 \\
\hline Burpee's Rhubarb Chard ${ }^{z}$ & 816.3 & 1018.7 \\
\hline Chioggia & 1131.3 & 1249.7 \\
\hline Detroit Dark Red $A^{x}$ & 1316.7 & 1611.0 \\
\hline Detroit Dark Red B ${ }^{\mathrm{x}}$ & 1290.9 & 1627.9 \\
\hline Detroit Dark Red C ${ }^{x}$ & 1146.8 & 1422.2 \\
\hline Early Wonder Tall Top & 1122.6 & 1404.9 \\
\hline Egitto Miglionata & 1080.8 & 1344.3 \\
\hline Forono & 1678.9 & 1909.5 \\
\hline Golden Eckendorf $^{y}$ & 875.4 & 989.3 \\
\hline Jaune de Vauriac & 797.8 & 967.7 \\
\hline Lutz Green Leaf & 1146.9 & 1365.3 \\
\hline Mammoth Long Red ${ }^{y}$ & 850.0 & 1031.0 \\
\hline Red Ace & 1359.7 & 1623.9 \\
\hline Rote Kugal & 1233.7 & 1463.9 \\
\hline Ruby Queen & 1197.7 & 1411.0 \\
\hline Touchstone Gold & 1091.9 & 1290.3 \\
\hline Yellow Detroit & 988.2 & 1264.5 \\
\hline $\begin{array}{c}\text { Least significant } \\
\text { difference }_{0.05}\end{array}$ & 155.5 & 192.3 \\
\hline
\end{tabular}

${ }^{\mathrm{z}}$ Swiss chard [B. vulgaris ssp. vulgaris (leaf beet group)] cultivar. ${ }^{y}$ Mangel [B. vulgaris ssp. vulgaris (fodder beet group)] cultivar. ${ }^{\mathrm{x}} \mathrm{A}=\mathrm{W}$. Atlee Burpee and Co., Warminster, PA; B = NE Seed, Hartford, CT; C = Seedway, Hall, NY.

The mean value across all cultivars for total oxalate level was $1326 \mathrm{mg} / 100 \mathrm{~g}$ leaf tissue. For table beet cultivars, the overall mean was $1408 \mathrm{mg} / 100 \mathrm{~g}$ leaf tissue. Red-rooted beets had an average of $1498 \mathrm{mg} / 100 \mathrm{~g}$ leaf tissue, whereas non-red-rooted beets (including chioggia) had an average of $1182 \mathrm{mg} / 100 \mathrm{~g}$ leaf tissue for a $21 \%$ difference. The two mangel cultivars (Mammoth Long Red and Golden Eckendorf) had an average of $1010 \mathrm{mg}$ / $100 \mathrm{~g}$ leaf tissue of total oxalate. This was $28 \%$ lower than the mean of table beet cultivars. Swiss chard cultivars had an average of $870 \mathrm{mg} / 100 \mathrm{~g}$ leaf tissue for total oxalate. These values were more than double those reported by Savage et al. (2000), although this may have been the result of differences in leaf maturity and environmental conditions. Total oxalate values for swiss chard were comparable to those observed by Chai and Liebman (2005). There was 38\% less total oxalate in swiss chard cultivars than in beet cultivars based on overall means. However, swiss chard is cultivated as a leaf crop and traits such as grittiness resulting from calcium oxalate may have been selected against.

The mean value across all cultivars for soluble oxalate levels was $1094 \mathrm{mg} / 100 \mathrm{~g}$ leaf tissue. Table beet cultivars averaged $1162 \mathrm{mg} / 100 \mathrm{~g}$ leaf tissue of soluble oxalate. Red-rooted beets 
had an average of $1239 \mathrm{mg} / 100 \mathrm{~g}$ leaf tissue, whereas non-redrooted beets had an average of $970 \mathrm{mg} / 100 \mathrm{~g}$ leaf tissue for a $22 \%$ difference. Mangel cultivars had an average of $863 \mathrm{mg} / 100 \mathrm{~g}$ leaf tissue and swiss chard cultivars had an average of $685 \mathrm{mg} / 100 \mathrm{~g}$ leaf tissue of soluble oxalate. This is $26 \%$ and $25 \%$ less soluble oxalate than was found in beet cultivars, respectively.

It is interesting to note that in the case of both soluble and total oxalate, mangel cultivars had intermediate levels in the leaves compared with beet and swiss chard cultivars. Mangel was originally bred from a cross between a red-rooted table beet and a white leaf beet (Goldman and Navazio, 2008). It is possible that mangel was created from an individual plant higher in oxalate crossed with a lower oxalate individual and the values we see today reflect this intermediacy. Additionally, because mangel is used as livestock feed in northern Europe, selection for increased palatability may be responsible for the levels observed.

The differences observed here have implications for cultivar selection. Leaves with higher total oxalate tend to belong to redrooted table beets, whereas non-red-rooted beets, chards, and mangels tend to have lower total oxalate levels. The same can be said for soluble oxalate levels in leaves. The hybrid cultivar selected for this study, Red Ace, had higher levels of total and soluble leaf oxalate than open-pollinated cultivars. Bikores, a red-rooted beet cultivar, exhibited intermediate levels of both total and soluble leaf oxalate across all cultivars. 'Jaune de Vauriac' and 'Blakoma', both nonpigmented beets, had the lowest levels of total and soluble leaf oxalate for beet cultivars.

Many beet cultivars are maintained as open-pollinated populations by different seed companies. To assess if significant differences exist between populations sold as the same cultivar, we sampled popular cultivar Detroit Dark Red from three different seed companies (Table 3). Seed company B (NE Seed, Hartford, CT) differed significantly from seed company C (Seedway, Hall, NY) in total oxalate, whereas seed company A (W. Atlee Burpee and Co., Warminster, PA) differed from seed source $\mathrm{C}$ significantly in soluble oxalate. Seed source $C$ had the lowest mean values. It appears that source $\mathrm{C}$ may be maintaining genotypes that result in lower levels of oxalate. Based on this, it is likely that other openpollinated cultivars maintained by different sources may have significant genetic variation in leaf oxalate. Genetic drift during the maintenance of these populations may be responsible for the observed differences.

It is also interesting to compare soluble and total oxalate values between the two plantings (Table 4). For both soluble and total oxalate, planting date had a significant effect
(Table 2). The standard planting date had a mean soluble oxalate value of $1213 \mathrm{mg} / 100 \mathrm{~g}$ leaf tissue and the late planting date had a mean value of $975 \mathrm{mg} / 100 \mathrm{~g}$ leaf tissue. This is a $20 \%$ decrease in soluble oxalate level when planting is deferred until midsummer. Leaf total oxalate values for the standard planting date were $1513 \mathrm{mg} / 100 \mathrm{~g}$ leaf tissue and for the late planting date they decreased to a mean of $1140 \mathrm{mg} / 100 \mathrm{~g}$ leaf tissue. The late planting had a decrease of $25 \%$ in total oxalate compared with the standard planting date.

These results have important implications for cultivation and human nutrition. By decreasing the growth period by planting later (or potentially harvesting earlier or in quick succession), beets or swiss chard grown as leaf crops can contain significantly reduced amounts of soluble and total oxalate. Nutritionally, this is important for two reasons; first, lowering soluble levels decreases the amount of bioavailable oxalic acid. For people trying to limit oxalate intake to prevent or lessen kidney stone formation, leaf crops with lower oxalic acid would be more acceptable to eat. Second, total oxalate levels decreased; therefore, we can conclude that insoluble oxalate may also decrease in part. Lower levels of insoluble oxalate may be nutritionally beneficial for people who consume dark

Table 4. Leaf mean soluble and total oxalate values based on planting date for the youngest fully developed leaf at vegetable maturity as determined by an enzymatic assay for 24 beet [Beta vulgaris ssp. vulgaris (garden beet group)] and related subspecies cultivars grown in replicated trials at Arlington, WI, in 2008-2009 and compared using a protected F test.

\begin{tabular}{|c|c|c|c|c|}
\hline \multirow[b]{3}{*}{ Cultivar } & \multicolumn{2}{|c|}{ Leaf soluble oxalate } & \multicolumn{2}{|c|}{ Leaf total oxalate } \\
\hline & \multicolumn{4}{|c|}{$(\mathrm{mg} / 100 \mathrm{~g}$ leaf tissue $)$} \\
\hline & $\begin{array}{c}\text { Standard } \\
\text { planting date }\end{array}$ & $\begin{array}{c}\text { Late planting } \\
\text { date }\end{array}$ & $\begin{array}{c}\text { Standard } \\
\text { planting date }\end{array}$ & $\begin{array}{c}\text { Late planting } \\
\text { date }\end{array}$ \\
\hline Big Top & 1637.5 & 1036.6 & 1985.9 & 1219.1 \\
\hline Bikores & 1178.4 & 1090.9 & 1575.0 & 1187.3 \\
\hline Blakoma & 794.6 & 862.3 & 1217.0 & 1028.8 \\
\hline Bolivar & 1276.7 & 1021.9 & 1590.5 & 1224.0 \\
\hline Bull's Blood & 1354.5 & 931.1 & 1701.4 & 1093.1 \\
\hline $\begin{array}{l}\text { Burpee's Fordhook } \\
\text { Giant Chard }\end{array}$ & 486.8 & 619.3 & 676.3 & 767.0 \\
\hline Burpee's Golden & 1038.8 & 928.3 & 1286.8 & 1109.8 \\
\hline Burpee's Rhubarb Chard ${ }^{\mathrm{z}}$ & 878.8 & 753.8 & 1091.7 & 945.6 \\
\hline Chioggia & 1145.5 & 1117.0 & 1282.1 & 1217.2 \\
\hline Detroit Dark Red A & 1444.8 & 1188.6 & 1805.7 & 1416.2 \\
\hline Detroit Dark Red B ${ }^{\mathrm{x}}$ & 1423.2 & 1158.5 & 1899.3 & 1356.6 \\
\hline Detroit Dark Red C ${ }^{\mathrm{x}}$ & 1250.8 & 1042.8 & 1601.2 & 1243.2 \\
\hline Early Wonder Tall Top & 1254.4 & 990.8 & 1662.1 & 1147.7 \\
\hline Egitto Miglionata & 1142.8 & 1018.9 & 1486.2 & 1202.3 \\
\hline Forono & 2005.3 & 1352.4 & 2239.0 & 1580.1 \\
\hline Golden Eckendorf ${ }^{\mathrm{y}}$ & 1020.3 & 730.5 & 1170.7 & 807.8 \\
\hline Jaune de Vauriac & 909.5 & 686.1 & 1158.3 & 777.1 \\
\hline Lutz Green Leaf & 1340.4 & 953.5 & 1636.5 & 1094.1 \\
\hline Mammoth Long Red ${ }^{\mathrm{y}}$ & 944.9 & 755.0 & 1210.0 & 852.0 \\
\hline Red Ace & 1556.6 & 1162.7 & 1835.7 & 1412.1 \\
\hline Rote Kugal & 1459.9 & 1007.4 & 1732.4 & 1195.5 \\
\hline Ruby Queen & 1349.4 & 1046.1 & 1608.3 & 1213.7 \\
\hline Touchstone Gold & 1209.0 & 974.8 & 1545.8 & 1034.8 \\
\hline Yellow Detroit & 1004.6 & 971.7 & 1305.6 & 1223.4 \\
\hline $\begin{array}{c}\text { Least significant } \\
\text { difference }_{0.05}\end{array}$ & 247.3 & 247.3 & 304.1 & 304.1 \\
\hline
\end{tabular}

${ }^{\mathrm{z}}$ Swiss chard [B. vulgaris ssp. vulgaris (leaf beet group)] cultivar.

${ }^{\mathrm{y}}$ Mangel [B. vulgaris ssp. vulgaris (fodder beet group)] cultivar.

${ }^{\mathrm{x}} \mathrm{A}=\mathrm{W}$. Atlee Burpee and Co., Warminster, PA; B =NE Seed, Hartford, CT; C = Seedway, Hall, NY. 
leafy greens to meet calcium or other mineral requirements. It is possible that decreased levels of insoluble oxalate might result in the increased bioavailability of calcium and other minerals. Further research would be needed to determine the relationship between calcium levels and oxalate, especially in regard to length of the growing period.

Rоoтs. We evaluated the interactions between year and cultivar for the standard planting date as a result of incomplete data for the late planting date. There were no significant interactions between year and cultivar for both root soluble and total oxalate, but year was significant for total root oxalate (Table 5). Additionally, we evaluated the interactions between planting date and cultivar for Year 1 as a result of incomplete data in Year 2. No significant interactions between planting date and cultivar were found for root soluble and total oxalate (Table $6)$. Although neither model indicated a significant interaction for year $\times$ cultivar or planting date $\times$ cultivar, cultivar was significant in all cases (Tables 5 and 6). Mean root total and soluble oxalate values were based on the standard planting date averaged over 2 years (Table 7).

The mean of root soluble oxalate for all cultivars was $141 \mathrm{mg} /$ $100 \mathrm{~g}$ root tissue. The mean value of all beet cultivars assessed was lower than the mangel cultivars, 140 and $152 \mathrm{mg} / 100 \mathrm{~g}$ root tissue, respectively. The range for root soluble oxalate was 103 to $171 \mathrm{mg} / 100 \mathrm{~g}$ root tissue. These values are, on average, three times larger than values of raw beet root reported by Savage et al.

Table 5. Analysis of variance using the PROC MIXED procedure of SAS (Version 9.1.3; SAS Institute, Cary, NC) for root soluble and total oxalate for 22 beet [Beta vulgaris ssp. vulgaris (garden beet group)] and mangel [B. vulgaris ssp. vulgaris (fodder beet group)] cultivar root core samples from roots taken from the standard planting date at vegetable maturity and grown in replicated trials at Arlington, WI, in 2008-2009.

\begin{tabular}{llrrrc}
\hline Trait & Source of variation & $\mathrm{df}_{\text {num }}{ }^{\mathrm{z}}$ & $\mathrm{df}_{\mathrm{den}^{\mathrm{y}}}$ & \multicolumn{1}{c}{$P$} & Significance \\
\hline Root soluble oxalate & Cultivar & 21 & 81 & 0.0001 & $* * *$ \\
& Year & 1 & 4 & 0.6996 & NS \\
& Year $\times$ cultivar & 21 & 81 & 0.4987 & NS \\
& Cultivar & 21 & 84 & $<0.0001$ & $* * *$ \\
Root total oxalate & Year & 1 & 4 & 0.0027 & $* *$ \\
& Year $\times$ cultivar & 21 & 84 & 0.1580 & NS \\
\hline
\end{tabular}

${ }^{\mathrm{z}}$ Numerator df.

${ }^{\mathrm{y}}$ Denominator df.

NS, $* * *, * * *$ Nonsignificant or significant at $P \leq 0.05,0.01$, or 0.001 , respectively.

Table 6. Analysis of variance using the PROC MIXED procedure of SAS (Version 9.1.3; SAS Institute, Cary, NC) for root soluble and total oxalate for 22 beet [Beta vulgaris ssp. vulgaris (garden beet group)] and mangel [B. vulgaris ssp. vulgaris (fodder beet group)] cultivar root core samples from roots taken from the standard and late planting dates at vegetable maturity and grown in replicated trials at Arlington, WI, in 2008.

\begin{tabular}{llrrrc}
\hline Trait & Source of variation & $\mathrm{df}_{\text {num }}{ }^{\mathrm{z}}$ & $\mathrm{df}_{\mathrm{den}^{\mathrm{y}}}$ & \multicolumn{1}{c}{$P$} & Significance \\
\hline Root soluble oxalate & Cultivar & 21 & 79 & 0.0030 & $* *$ \\
& Planting date & 1 & 4 & 0.9814 & $\mathrm{NS}$ \\
& Planting date $\times$ cultivar & 21 & 79 & 0.8726 & NS \\
Root total oxalate & & & & \\
& Cultivar & 21 & 81 & $<0.0001$ & $* * *$ \\
& Planting date & 1 & 4 & 0.2959 & NS \\
& Planting date $\times$ cultivar & 21 & 81 & 0.3192 & NS \\
\hline
\end{tabular}

\footnotetext{
${ }^{\mathrm{z}}$ Numerator df.

yenominator df.

NS, *,***** Nonsignificant or significant at $P \leq 0.05,0.01$, or 0.001 , respectively
}

(2000) and over two times larger than values reported by Chai and Liebman (2005) on raw beet root. Levels are smaller than for pickled beet root reported by Kasidas and Rose (1980).

(n) 2005) and over two times as large as values for raw beet root Total oxalate levels ranged from 95 to $141 \mathrm{mg} / 100 \mathrm{~g}$ root 'Blakoma', a non-pigmented beet, had the highest total oxalate Red-rooted beet cultivar Bolivar had the lowest total ( $\%$ of the cultivars studied (Table 7 )

Detroit Dark Red cultivars did not differ significantly from $101 \mathrm{mg} / 100 \mathrm{~g}$ root tissue of total oxalate. From this we conclude hat the seed companies tested are not maintaining populations expression of oxalate in roots. implications for nutrition and cultivation. However, there appear to be cultivars higher or lower in soluble or total root oxalate levels. For example, 'Detroit Dark Red' (seed company A) exhibited $40 \%$ less soluble oxalate than 'Burpee's Golden'. Because there was no significant effect of planting date on root oxalate levels, changing cultivation techniques by planting later in the season may not be a useful technique to reduce oxalate levels. By contrast, there was a significant effect of planting date for leaf oxalate; it is possible that roots maintain a more constant level of oxalic acid, whereas additional acid accumulated over a longer growing season is either stored or produced in the leaves. A grower might not have to sacrifice yield in mass to produce a lower oxalate root.

Correlation. We evaluated the relationships between soluble and total oxalate in the roots and leaves as well as between roots and leaves (Table 8). Root total oxalate was highly significantly correlated with root soluble oxalate. The same was true for leaf total and soluble oxalate. Root total oxalate was not significantly correlated with leaf total oxalate. Root soluble oxalate was also not significantly correlated with leaf soluble oxalate. Therefore, there is no significant relationship between root oxalate and leaf oxalate when considering all cultivars. However, some cultivars exhibited an inverse relationship between root and leaf oxalate such as Red Ace and Detroit Dark Red (seed companies A 
Table 7. Root mean soluble and total oxalate values for 22 beet [Beta vulgaris ssp. vulgaris (garden beet group)] and mangel [B. vulgaris ssp. vulgaris (fodder beet group)] cultivar root core samples from roots at vegetable maturity and grown in replicated trials at Arlington, WI, in 2008-2009 and compared using a protected F test.

\begin{tabular}{|c|c|c|}
\hline \multirow[b]{2}{*}{ Cultivar } & Root soluble oxalate & Root total oxalate \\
\hline & \multicolumn{2}{|c|}{$(\mathrm{mg} / 100 \mathrm{~g}$ root tissue $)$} \\
\hline Big Top & 148.2 & 131.9 \\
\hline Bikores & 154.8 & 130.6 \\
\hline Blakoma & 153.0 & 141.6 \\
\hline Bolivar & 117.3 & 94.6 \\
\hline Bull's Blood & 151.7 & 119.8 \\
\hline Burpee's Golden & 170.9 & 137.7 \\
\hline Chioggia & 158.3 & 125.3 \\
\hline Detroit Dark Red A ${ }^{y}$ & 103.1 & 102.1 \\
\hline Detroit Dark Red B ${ }^{\mathrm{y}}$ & 111.7 & 99.9 \\
\hline Detroit Dark Red C & 118.7 & 102.2 \\
\hline Early Wonder Tall Top & 149.3 & 129.9 \\
\hline Egitto Miglionata & 144.0 & 126.3 \\
\hline Forono & 166.7 & 139.9 \\
\hline Golden Eckendorf ${ }^{z}$ & 147.5 & 134.4 \\
\hline Jaune de Vauriac & 133.2 & 118.8 \\
\hline Lutz Green Leaf & 161.5 & 136.0 \\
\hline Mammoth Long Red ${ }^{\mathrm{z}}$ & 156.7 & 123.1 \\
\hline Red Ace & 112.2 & 95.8 \\
\hline Rote Kugal & 115.5 & 111.2 \\
\hline Ruby Queen & 136.7 & 120.0 \\
\hline Touchstone Gold & 154.6 & 130.1 \\
\hline Yellow Detroit & 145.8 & 126.0 \\
\hline $\begin{array}{l}\text { Least significant } \\
\text { difference }_{0.05}\end{array}$ & 65.8 & 22.2 \\
\hline
\end{tabular}

${ }^{\mathrm{z}}$ Mangel cultivar.

${ }^{\mathrm{y}} \mathrm{A}=\mathrm{W}$. Atlee Burpee and Co., Warminster, PA; B = NE Seed, Hartford, CT; C = Seedway, Hall, NY.

Table 8. Correlation coefficients and significance of root and leaf oxalate comparisons for beet [Beta vulgaris ssp. vulgaris (garden beet group)] and related sub-species sampled at vegetable maturity and grown in replicated trials at Arlington, WI, in 2008-2009.

\begin{tabular}{lccc}
\hline Comparisons & $\begin{array}{c}\text { Correlation } \\
\text { coefficient }\end{array}$ & $P$ & Significance \\
\hline $\begin{array}{l}\text { Root total oxalate and root } \\
\text { soluble oxalate }\end{array}$ & 0.55 & $<0.0001$ & $* * *$ \\
$\begin{array}{c}\text { Leaf total oxalate and leaf } \\
\text { soluble oxalate }\end{array}$ & 0.89 & $<0.0001$ & $* * *$ \\
$\begin{array}{c}\text { Root total oxalate and leaf } \\
\text { total oxalate }\end{array}$ & 0.06 & 0.4388 & NS \\
$\begin{array}{c}\text { Root soluble oxalate and } \\
\text { leaf soluble oxalate }\end{array}$ & -0.13 & 0.0775 & NS \\
\hline
\end{tabular}

NS, *,**,*** Nonsignificant or significant at $P \leq 0.05,0.01$, or 0.001 , respectively.

and $\mathrm{B}$, respectively). A smaller value in root levels compared with the leaves might be related to oxalate production over time. Because oxalate accumulates in the roots, it may be diluted as the root swells as a result of water absorption. Compared with root levels, oxalate production may also be higher in leaves to serve as an insect defense mechanism.

\section{Conclusions}

Overall, values for both unprocessed leaf and root oxalate were either higher than or comparable to those reported in other studies surveying beet and other related species (Chai and Liebman, 2005; Kasidas and Rose, 1980; Mou, 2008; Savage et al., 2000). There are three potential reasons contributing to higher values measured in this study. Cultivar selection is often unnoted in the literature and may affect levels significantly. Second, environmental differences during plant growth may result in different levels. Third, harvest time or duration in the field can alter oxalate values (Massey, 2007). For example, we did not harvest either greens or roots at the time they would have been considered ready for use as baby salad greens or fresh market sale, respectively. This allowed for oxalate to continue accumulating as the plant aged (Singh and Saxena, 1972). This additional field time beyond what is normal for fresh market beets or salad beet greens limits comparisons among surveys done with shorter season crops such as spinach or storepurchased leaf and root crops.

We determined that there was a substantial range of leaf oxalate values among beet, chard, and mangel cultivars, suggesting that some genetic variability for this trait exists. The oxalate content of other high oxalate crops is lower than in beet. For example, common spinach cultivars have reported soluble oxalate values ranging from 840 to $1212 \mathrm{mg} / 100 \mathrm{~g}$ fresh weight (Mou, 2008). Rhubarb stalks (Rheum rhaponticum) have exhibited total oxalate levels of $\approx 987 \mathrm{mg} / 100 \mathrm{~g}$ (Savage et al., 2000). When considering oxalate levels observed in this experiment in the context of reported values of other high oxalate foods, both beet leaves and roots in general exhibited oxalate levels much higher than the high oxalate foods (Tables 3 and 7). Even cultivars in the second planting, which produced leaves of an age closer to what would be harvested for baby greens salad mixes, frequently exhibited soluble and total oxalate levels much higher than a high oxalate food (Table 4). The same can be said for beet roots in the second planting, which were harvested at a size more akin to a fresh market beet.

Breeding efforts using Chenopodiaceae germplasm face challenges to lower either soluble or total oxalate levels significantly enough to the point at which beet will ever be considered a lower oxalate food. However, useful gains may be made. It may be possible to lower the oxalate content of a beet cultivar with higher oxalate levels by crossing with a lower oxalate beet, swiss chard, or mangel cultivar. This would take time as a result of the biennial nature of beet and the more classical breeding methods currently used because it is possible to accomplish only one generation of breeding per year, even under ideal conditions. In addition, if crossing to swiss chard or mangel, many generations of backcrosses would be required to regain the desired parental table beet genotype. However, classical breeding approaches have been successful in improving table beet and may be successful here. Heritability of oxalate content is unknown in beet, although it has been reported to have low narrow-sense heritability in rhubarb (Libert, 1987). Reducing soluble oxalate in processed roots may be a possibility in the future as new enzymatic technologies are developed that help break down oxalate (Betsche and Fretzdorff, 2005).

Understanding the relationship between calcium and oxalate better would be useful to increase bioavailable calcium in beet roots and especially in leaves. For example, breeding for higher calcium content may not improve bioavailability if soluble 
oxalate levels remain high, thus increasing potential for the binding of accessible calcium. Because oxalate functions as a storage site for calcium, it is also unknown what effect altering the calcium/oxalate balance may do to the viability or quality of the plant.

As a result of both its relationship with nutrition and disease, oxalate is a compound of interest. Table beet roots and leaves are high in both soluble and total oxalate. Significant variation exists within leaves and roots. Breeding to lower oxalate levels a significant amount may be possible yet challenging despite available germplasm. Using cultivation techniques such as delaying planting may be a better alternative to minimize oxalate levels. Further research on the relationship between oxalate and calcium may provide additional information that could illuminate alternative approaches to breeding for a lower oxalate table beet.

\section{Literature Cited}

Albihn, P.B.E. and G.P. Savage. 2001. The effect of cooking on the location and concentration of oxalate in three cultivars of New Zealandgrown oca (Oxalis tuberosa Mol). J. Sci. Food Agr. 81:1027-1033.

Betsche, T. and B. Fretzdorff. 2005. Biodegradation of oxalic acid from spinach using cereal radicles. J. Agr. Food Chem. 53:9751-9758.

Brogren, M. and G. Savage. 2003. Bioavailability of soluble oxalate from spinach eaten with and without milk products. Asia Pac. J. Clin. Nutr. 12:219-224.

Chai, W. and M. Liebman. 2005. Effect of different cooking methods on vegetable oxalate content. J. Agr. Food Chem. 53:3027-3030.

Chang, C.-C. and H. Beevers. 1968. Biogenesis of oxalate in plant tissues. Plant Physiol. 43:1821-1828.

Council on Renal Nutrition. 2009. Diet and kidney stones. 2 Nov. 2009. <http://www.kidney.org/atoz/content/diet.cfm>.

Franceschi, V.R. 1989. Calcium oxalate formation is a rapid and reversible process in Lemna minor L. Protoplasma 148:130-137.

Franceschi, V.R. and F.A. Loewus. 1995. Oxalate biosynthesis and function in plants and fungi, p. 113-130. In: Khan, S.R. (ed.). Calcium oxalate in biological systems. CRC Press, Boca Raton, FL.

Goldman, I.L. and J.P. Navazio. 2008. Table beet, p. 219-238. In: Prohens, J. and Nuez F. (eds.). Vegetables I: Asteraceae, Brassicaceae, Chenopodicaceae, and Cucurbitaceae. Springer, New York, NY.

Hodgkinson, A. 1977. Oxalic acid in biology and medicine. Academic Press, London, UK.

Holmes, R.P., H.O. Goodman, and D.G. Assimos. 2001. Contribution of dietary oxalate to urinary oxalate excretion. Kidney Intl. 59:270-276.

Honow, R. and A. Hesse. 2002. Comparison of extraction methods for the determination of soluble and total oxalate in foods by HPLCenzyme-reactor. Food Chem. 78:511-521.
Kaminishi, A. and N. Kita. 2006. Seasonal change of nitrate and oxalate concentration in relation to the growth rate of spinach cultivars. HortScience 41:1589-1595.

Kasidas, G.P. and G.A. Rose. 1980. Oxalate content of some common foods: Determination by an enzymatic method. J. Hum. Nutr. 34: 255-266.

Korth, K.L., S.J. Doege, S.-H. Park, F.L. Goggin, Q. Wang, S.K. Gomez, G. Liu, L. Jia, and P.A. Nakata. 2006. Medicago truncatula mutants demonstrate the role of plant calcium oxalate crystals as an effective defense against chewing insects. Plant Physiol. 141:188-195.

Libert, B. 1987. Breeding a low-oxalate rhubarb (Rheum sp. L.). J. Hort. Sci. 62:523-529.

Libert, B. and V.R. Franceschi. 1987. Oxalate in crop plants. J. Agr. Food Chem. 35:926-938.

Ma, Z. and S.C. Miyasaka. 1998. Oxalate exudation by taro in response to Al. Plant Physiol. 118:861-865.

Massey, L.K. 2007. Food oxalate: Factors affecting measurement, biological variation, and bioavailability. J. Amer. Dietetic Assn. 107: 1191-1194.

Morita, A., R. Suzuki, and H. Yokota. 2004. Effect of ammonium application on the oxalate content of tea plants (Camellia sinensis L.). Soil Sci. Plant Nutr. 50:763-769.

Morris, J., P.A. Nakata, M. McConn, A. Brock, and K.D. Hirschi. 2007. Increased calcium bioavailability in mice fed genetically engineered plants lacking calcium oxalate. Plant Mol. Biol. 64: 613-618.

Mou, B. 2008. Evaluation of oxalate concentration in the U.S. spinach germplasm collection. HortScience 43:1690-1693.

Nakata, P.A. and M.M. McConn. 2006. A genetic mutation that reduces calcium oxalate content increases calcium availability in Medicago truncatula. Funct. Plant Biol. 33:703-706.

Nuss, R.F. and F.A. Loewus. 1978. Further studies on oxalic acid biosynthesis in oxalate-accumulating plants. Plant Physiol. 61: 590-592.

Robertson, W.G. and B.E.C. Nordin. 1969. Activity products in urine. Proc. Renal Stone Res. Symp. p. 221-232.

Ruiz, N., D. Ward, and D. Saltz. 2002. Responses of Pancratium sickenbergeri to simulated bulb herbivory: Combining defense and tolerance strategies. J. Ecol. 90:472-479.

Savage, G.P., L. Vanhanen, S.M. Mason, and A.B. Ross. 2000. Effect of cooking on the soluble and insoluble oxalate content of some New Zealand foods. J. Food Compost. Anal. 13:201-206.

Singh, P.P. and S.N. Saxena. 1972. Effect of maturity on the oxalate and cation contents of six leafy vegetables. Indian J. Nutr. Diet. 9: 269-276.

Yang, J.C. and F.A. Loewus. 1975. Metabolic conversion of Lascorbic acid to oxalic acid in oxalate-accumulating plants. Plant Physiol. 56:283-285. 